Addresses giving various phases of $\mathrm{Mr}$. Cushing's life and work were then made by President W J McGee, Major J. W. Powell, of the Bureau of Ethnology, in which Bureau Mr. Cushing was a brilliant worker, Mr. L. O. Howard, Secretary American Association for the Advancement of Science, who was a classmate in Cornell ; Professor W. H. Holmes, spoke of his work for the National Museum; Mr. Stuart Culin, of his researches in behalf of the University of Pennsylvania; Mr. J. D. McGuire, of his genius in the technological and archæological field; Dr. Washington Matthews, of his discoveries in Zuni and the Salado Valley and of his organization and explorations with the Hemenway expedition; Mr. P. B. Pierce, of his character as a personal friend; Miss Alice C. Fletcher, of Mr. Cushing's wonderful mind and his ability to discern similarities and forge the connecting links between the thoughts of primitive man and the archæic remains with which he was surrounded. The consensus of opinion was that Mr. Cushing occupied a field peculiarly his own and that he ranked as one of the few real geniuses of the world.

Letters of regret were read from Dr. Franz Boaz, of the American Museum of Natural History and Mr. Wm. Wallace Tooker and Wells M. Sawyer.

The resolutions were adopted by a rising vote.

\section{J. H. MaCormick.} Secretary.

\section{DISCUSSION AND CORRESPONDENCE.}

\section{HUMANIZING THE BIRDS.}

Bird Lore for December last contained an excellent article by Caroline G. Soule, entitled 'Humanizing the Birds,' and protesting against the too common practice of ascribing to them human qualities which they do not possess and mental traits with which they are not endowed. The title might well serve as the text for a long discourse on the subject, for there is all too much of this 'humanizing' indulged in now-adays, not only by those who write about birds, but by writers in all branches of natural history, and it is not confined to stories written for the instruction of small children, but in articles intended for the edification of children of a much larger growth. Writers on evolution are all too prone to humanize their subjects, and it is so favorite a sin with those discussing problems of mimicry that in his Dictionary of Birds Professor Newton follows that caption 'with the prefix unconscrous, which in every department of zoology should always be expressed or understood.' For it is a common fault to make the mimicking process active instead of passive, to say, for example, that "Many butterflies escape destruction by mimicking the colors and markings of uneatable forms," as if the butterflies had given serious thought to the matter. When an author writes that "Butterflies are often attracted by the excreta of birds and a spider takes advantage of this fact to secure his prey," he implies a considerable amount of reasoning power in the spider. That this implication is not intended is shown a little later by the statement that "The whole combination of habits, form and coloring afford a wonderful example of what natural selection can accomplish," but the damage has been done and the suggestion made that the mimicry is intentional.

When we read that the "witch-hazel, knowing that neither boy nor girl, nor bird nor beast nor wind, will come to the rescue of its little ones, is obliged to take matters into its own hands" we realize that it was written for a child, although we may deplore this manner of writing and wish that the case had been differently stated. But here is a statement almost, if not quite as bad, taken from an important work on zoology and not written with the view of interesting a child: "In the Mediterranean the embryos [of sponges] $* * *$ escape from the tissues of the parent when they have arrived at the blastula condition $* * *$, in the same species on the shores of the English Channel the young are retained until after gastrulation ***." The explanation of this it is said is not difficult: "In the Mediterranean there are no strong currents and is evidently best for the parents to get rid of the young at as early a moment as possible, thus escaping longer drain upon its energies. In the English Channel, on the other hand, the current is very strong, and were the embryos to be set free at the stage at which they are in the Medi- 
terranean the chances are that they would be swept away $* * *$, and hence they are retained (italics ours) until nearly ready for attachment to the rocks." This seems to be a direct transposition of cause and effect and credits the lowly sponge with an amount of reasoning power and a degree of intelligence that few have suspected it to possess. Why would it not have been quite as accurate and decidedly less confusing to have said that, while we do not know, it seems probable that in the first case we have the normal condition of affairs, while in the second there has been an elimination of those sponges whose young were turned loose into a cold world at too tender an age?

These are merely one or two examples, the first that came to hand, of a very prevalent style of writing, but they serve as typical examples of a familiar class. Such statements as these are made with a view of popularizing science by making it pleasant reading, but it may be questioned if this mode of writing does not merely fail of producing its intended effect, but creates an entirely erroneous impression in the minds of the non-scientific reader for whom it is meant. Does it not teach that evolution is not a passive but an active process, and subtly lead him to think that not only the higher, but the lower animals, even the plants, pass many anxious moments considering what they may do for the benefit of posterity? Sooner than leave such an impression as this it would seem best to cease 'humanizing the birds.'

\section{F. A. LuCAs.}

\section{NOTES ON INORGANIC CHEMISTRY.}

IN the last number of Nature, W. A. Shenstone and H. C. Lacell, of Clifton College, contribute an interesting paper on working silica in the oxy-gas blow-pipe flame. While Gaudin had observed the elasticity of fine threads of vitreous silica as early as 1839 , it was not till Professor C. V. Boys rediscovered the valuable qualities of 'quartz threads' in 1887 that the working of silica in the blow-pipe flame became practical. The authors have done much work with silica which is described in the paper. They find it possible to make thermometer tubes of silica and express the view that the only limit in its application is the matter of ex- pense. They note in conclusion certain properties : It is harder than feldspar, but less hard than chalcedony, and its surface appears equally hard, whether cooled rapidly or slowly; the cold vitreous silica can be plunged safely into the hottest part of the oxy-gas flame, and thick rods and tubes of silica can be heated till plastic and then plunged into cool water without injury ; vitreous silica is a very poor conductor of heat and hence it is possible to hold a thick rod of silica very close to a strongly ignited zone. Great developments in chemical and physical laboratories may be expected when it becomes possible to use apparatus of silica, which, in addition to possessing an extreme resistance, will endure the greatest and most rapid variations of temperature.

IN a paper read before the Royal Society of Dublin, by James Holmes Pollok, a new deposit of kieselguhr is described as occurring in County Antrim, along both banks of the Lower Bann from Toome Bridge, where the river emerges from Lough Neagh, down to Coleraine at its mouth. The deposit rests on peat and is only covered by vegetation. In places it is four feet in thickness. After drying in the sun, the material is pure white, porous and very light, the specific gravity of the mass being only 0.5422 . The deposit is probably now being augmented when the river overflows its banks, and is largely composed of cubical diatoms from Lough Neagh.

A PAPER in the Zeitschrift für anorganische Chemie, by W. Hempel and v. Haasy, on amorphous silicon brings out seyeral new facts in an old subject. By the action of sodium on the fluorid of silicon and subsequent fusion of the powdered mass with aluminum, a very active form of amorphous silicon is obtained on dissolving out the aluminum. This silicon burns very readily when heated gently in the air. Heated in chlorin it gives easily silicon chlorid. By direct union with sulfur, silicon disulfid is formed, which is purified by sublimation, forming long white needles, similar to the product described by Sabatier as being formed by heating silicon in a current of hydrogen sulfid. On fusion with sodium sulfid, sodium metathiosilicate $\mathrm{Na}_{2} \mathrm{SiS}_{3}$, is formed corresponding to so- 